\title{
Tumorőssejtek szerepe a melanoma progressziójában és heterogenitásában
}

\author{
Széky Balázs ${ }^{1}$ - Silló Pálma dr. ${ }^{2}$ - Fábián Melinda dr. ${ }^{2}$ - Mayer Balázs dr. ${ }^{2}$ \\ Kárpáti Sarolta dr. ${ }^{2}$ - Németh Krisztián dr. ${ }^{2}$ \\ ${ }^{1}$ Pázmány Péter Katolikus Egyetem, Információs Technológiai és Bionikai Kar, Budapest \\ ${ }^{2}$ Semmelweis Egyetem, Általános Orvostudományi Kar, Bőr-, Nemikórtani és Bőronkológiai Klinika, Budapest
}

\begin{abstract}
A szolid és hematológiai tumorok legtöbbjében mára olyan sejtpopulációkat azonosítottak, amelyek a daganatok kis százalékát alkotják, mégis kiemelkedő szerepet töltenek be a daganat terjedésének előmozdításában. Ezek az úgynevezett tumorőssejtek a szomatikus és embrionális őssejtekhez hasonló viselkedést mutatnak, aszimmetrikus osztódással önmegújításra képesek és heterogén sejtpopulációkat is létrehoznak. Egyre több kutatás alátámasztja, hogy a malignus melanomák progressziója mögött is tumoros őssejtek állnak. Nem tisztázott kérdés azonban, hogy a tumorigenicitásért vajon kizárólag melanomaőssejtek szubpopulációi felelősek vagy pluripotens őssejtté bármely melanomasejt dedifferenciálódhat. Jelen közlemény a pluripotens melanomaőssejtekról kíván átfogó képet nyújtani, különös tekintettel azokra a mechanizmusokra, amelyek a melanocyta-őssejtek differenciálódását szabályozzák, ugyanakkor a melanomaőssejtekben szabályozatlanul múködnek. Bemutatásra kerül a mikrokörnyezet sejtjeinek, sejtadhéziós molekuláinak és szolúbilis faktorainak szerepe a melanomák progressziójában és heterogenitásának kialakulásában. Végül szó esik a melanoma terjedését leíró modellekről és azokról a sejtszintű markerekről, amelyek a melanomaőssejtek elkülönítésére, újabb célzott terápiák kifejlesztésére lehetőséget nyújthatnak. Orv. Hetil., 2016. 157(34), 1339-1348.
\end{abstract}

Kulcsszavak: melanoma, tumorőssejt, mikrokörnyezet, marker

\section{Role of cancer stem cells in the progression and heterogeneity of melanoma}

Over the past decade a rare cell population called cancer stem cells has been identified in both solid tumors and hematologic cancers. These cells are reminiscent of somatic and embryonic stem cells and play a critical role in the initiation and progression of malignancies. As all stem cells, they are able to undergo asymmetric cell division and hence renew themselves and create various other progenies with heterogenous phenotypes. A growing body of literature suggested that stem cell subpopulations contribute significantly to the growth and metastatic properties of melanoma. This review gives a comprehensive overview of the current literature on melanoma stem cells, with a special emphasis on the signaling pathways responsible for the homeostatic growth of melanocytes and the uncontrolled proliferation of melanoma cells. The importance of the local microenvironment are demonstrated through summarizing the role of various cell types, soluble factors and cell adhesion molecules in the progression of melanoma and the creation of treatment resistant cancer cell clones. Last but not least, the models of melanoma progression will be introduced and a variety of cellular markers will be presented that may be used to identify and therapeutically target melanoma.

Keywords: melanoma, cancer stem cell, microenvironment, marker

Széky, B., Silló, P., Fábián, M., Mayer, B., Kárpáti, S., Németh, K. [Role of cancer stem cells in the progression and heterogeneity of melanoma]. Orv. Hetil., 2016, 157(34), 1339-1348.

(Beérkezett: 2016. március 30; elfogadva: 2016. június 3.)

\section{Rövidítések}

ADCC = antigénfüggó celluláris citotoxicitás; ALDHl = aldehid-dehidrogenáz-1; BMP = csont morfogenikus fehérje; dab2 = disabled homolog-2; DCT = dopachrom-tautomeráz;
FGF2 = fibroblast-növekedési faktor-2; HMG-CoA = 3-hidroxi-3-metilglutaril-koenzim A; IGF = inzulinszerú növekedési faktor; IL-6 = interleukin-6; JARIDIB = Jumonji/AT rich interactive domain $1 \mathrm{~B} ; \mathrm{mab}=$ monoklonális antitest; $\mathrm{MClR}=$ 
melanokortin-receptor-1; Mitf = microphthalmia-asszociált transzkripciós faktor; $\mathrm{MM}=$ melanoma malignum; $\mathrm{MMP9}=$ mátrixmetalloproteáz-9; NID = Notch intracelluláris domén; NOD $/$ SCID $=$ non-obese diabetic/severe combined immunodefficient; Pax3 = paired box $3 ; \mathrm{PDGF}=$ vérlemezke-eredetû növekedési faktor; RPBJ- $\kappa=$ recombinant signal binding protein for immunoglobulin kappa-J; RGP = radiális növekedési fázis; SCF = óssejtfaktor; SDFl = stromaeredetű faktor-1; $\mathrm{SHH}=$ Sonic hedgehog; Sox $10=($ sex determining region $\mathrm{Y})-$ box $10 ;$ SRFl = szérum-reszponzívfaktor- 1 ; TGF- $\beta=$ transzformáló növekedési faktor- $\beta$; TNF- $\alpha=$ tumornekrózis-faktor- $\alpha$; $\mathrm{TNM}=$ tumorméret/nyirokcsomó/metasztázis; VE-cadherin = vascularis-endothelialis cadherin; VEGF = vascularis endothelialis növekedési faktor; VGP = vertikális növekedési fázis; $\mathrm{Wntl} / 3 \mathrm{a}=$ wingless $/$ integrated $-1 /-3 \mathrm{a}$

A melanoma malignum (MM, melanoma) egy rendkívül agresszív, metasztatizáló hajlamú és terápiarezisztens daganat. Noha az összes bőrdaganatnak kevesebb mint 3-5\%-át teszi ki, a bórrákos betegségek által okozott halálozások több mint 75\%-át adja [1]. A melanoma azért is különösen veszélyes, mivel a többi daganattípushoz viszonyítva már az alig tapintható, vékony primer tumor is képes metasztázisokat létrehozni. Míg a primer tumorok több mint 95\%-a sebészeti beavatkozással gyógyítható, a nyirokcsomó-metasztázist hordozó betegek 5 éves túlélési aránya már 50\%-ra csökken [2], a visceralis metasztázisok pedig kritikusan alacsony, néhány hónapos medián túlélési rátával társulnak.

A melanoma a melanocyták malignus transzformációjaként alakul ki, amelyet UV indukálta napfénykárosodás vagy nem UV-indukált onkogén mutációk okozhatnak [3]. A melanoma legfőbb rizikófaktora az intermittáló UV-expozíció, különösen akkor, ha napégéssel társul korai gyermekkorban. Az UVA által indukált oxidatív károsodás, valamint az UVB által indukált mutációk leggyakrabban a Braf $(50 \%)$ és Nras $(20 \%)$ aktiváló mutációit okozzák [4]. A melanoma kialakulását számos protoonkogén és tumorszuppresszor gén megváltozása okozhatja, az érintett allélokat magas, mérsékelt és alacsony kockázatú kategóriákba sorolják. Magas kockázatú allélnak számítanak például a $C D K N 2 A, C D K 4$ és a pI4ARF mutációi. A familiáris eredetû melanomák esetében a CDKN2A és a p14ARF mutációk az esetek 30\%-ában jellemzőek, a $C D K 4$ és a $C D K N 2 A$ csíravonali mutációi azonban a familiáris eredetû́ melanomáknál ritkának számítanak [5]. A melanocortin-1-receptor (MClR) és a pheomelanin eumelaninná való átalakításában részt vevő tirozináz és Tyrp-1 enzimek bizonyos genetikai polimorfizmusai szintúgy hajlamosító tényező́k lehetnek [6].

A melanomák szöveti lokalizációjuk és progressziójuk szerint öt csoportba sorolhatók. Kialakulás tekintetében a melanoma lehet naevus pigmentosus talaján kialakult (veleszületett vagy szerzett) MM - a pigmentált anyajegyen MM-sajátosságok, úgymint aszimmetria, elmosódott szöveti határ, heterogén pigmentáció, növekedés, vérzés, ulceratio alakulnak ki, de az esetek jelentősebb százalékában de novo, ép bőrön képződik MM. A TNMbeosztás alapján a tumor vastagsága, ulceratiója, nyirokcsomókba, valamint távoli szervekbe adott áttétei szerint a melanomák négy fó stádiumba sorolhatók. A környéki nyirokcsomók mellett az MM a nyirokutakon és véráramon át közeli és távoli áttéteket adhat bőrbe, valamint a máj, a tüdő, az agy, a gastrointestinalis traktus és a csontok is érintettek lehetnek.

$\mathrm{Az}$ in situ, intraepithelialis, széli terjedést mutató (radial growth phase - RGP) melanomasejtek osztódását a keratinocyták által termelt növekedési faktorok is befolyásolják, és ezek a tumorsejtek sejtkultúrákban képtelenek letapadás nélküli növekedésre. A vertikális növekedést mutató (vertical growth phase - VGP) melanomák ezzel szemben dermalis és subcutan rétegekben terjedve is osztódnak, és osztódásuk, valamint túlélésük független a keratinocyták növekedési faktoraitól és sejtadhéziós fehérjéitól, míg a dermalis fibroblastok a tumor progreszszióját és metasztázis képzését támogató mikrokörnyezetet hozhatnak létre körülöttük [7]. A kemoterápiás szerekre kialakuló rezisztencia egyik legfőbb forrásának tûnik a melanoma heterogenitása, amelynek kialakulásához az apoptotikus jelpályák és az antitumor-immunitás hatékony gátlása mellett a tumor mikrokörnyezetében található sejtes elemek és az általuk kibocsátott faktorok is hozzájárulnak [8]. A melanoma-asszociált fibroblastok által kibocsátott citokinek (IL-6), kemokinek (CCL2, CXCL-12), valamint fibroblast-, inzulinszerû és vérlemezke-eredetű növekedési faktorok (FGF2, IGF, PDGF) és angiogenezist promótáló hormonok (vascularis-endothelialis növekedési faktor - VEGF) kiemelkedő szerepet játszanak a melanoma növekedését elősegítő szöveti niche kialakulásában [7]. A tumorasszociált mikrokörnyezet a melanomasejtekben bizonyos ABC-transzporterek és drogmetabolikus enzimek expressziójának fokozódását is elősegíti. A tirozinkináz-gátlókkal szemben gyorsan kialakuló, nagymértékú rezisztenciát is ezzel magyarázzuk. A hatékony terápiás stratégiák kifejlesztéséhez meg kell ismernünk azokat a sejtszintű mechanizmusokat, amelyek a tumorok terjedése és a heterogén melanoma-szubpopulációk kialakulása mögött állnak.

Számos protoonkogént azonosítottak, amelyek csírabeli vagy szomatikus mutációja, illetve szabályozatlan expressziója a melanocyták malignus transzformációjára hajlamosít. Ezek közül kiemelendő a Brafp.V600E aktiváló mutációja, amely az UV-indukált primer és metasztatikus melanomák mintegy 20-50\%-ában jelen van, a betegek túlélési esélyeit nagymértékben csökkenti [9]. A melanoma mucosalis, uvealis és akrolentiginózus formáiban más onkogén mutációk a gyakoribbak (c-Kit, GNAQ [10]. A korábbi feltételezések szerint a tumoros transzformáció során - onkogén mutációk és szomatikus génexpressziós változások következtében - heterogén tumorklónok keletkeznek, amelyek közül klonális szelekcióval a drogrezisztens és metasztázist képző szubpopulációk válogatódnak ki (klonális hipotézis). 
Mostanra azonban a melanomákban és más tumorokban is felfedeztek olyan sejteket, amelyek a szöveti őssejtekhez hasonló viselkedést mutatnak, korlátlanul osztódnak, valamint képesek heterogén tumoros sejtvonalak létrehozására. Tumorőssejteket elsőként John E. Dick és Dominique Bonnet írtak le, akik az akut leukaemiában olyan sejteket azonosítottak, amelyek a haemopoeticus őssejtekre jellemző tulajdonságokat és fehérjemarkereket hordoztak. Ezek a sejtek immunszupprimált $\left(\mathrm{NOD}^{-} /\right.$ $\left.S C I D^{-}\right)$egérbe ültetve korlátlanul osztódtak és heterogén leukaemiás sejtvonalakat hoztak létre [11]. Dick és Bonnet úttörő munkásságát követően az emlő- és vastagbéltumorokban, valamint a glioblastomákban is elkülönítettek olyan speciális sejtklónokat, amelyek a tumorok heterogén szubpopulációinak létrehozásáért, fenntartásáért és propagációjáért felelősek [12]. A tumorőssejthipotézist az is alátámasztja, hogy a tumorigenicitással felruházott sejtek túlélését, rezisztenciáját és differenciációs potenciálját a szöveti őssejtekben is múködő jelpályák befolyásolják [13]. Szintén a tumorössejt-hipotézis mellett szól, hogy az említett sejtklónokon olyan jellegzetes sejtfelszíni markerek expresszálódnak, amelyek az embrionális vagy szomatikus őssejtekre jellemzők. A tumorőssejtek nem feltétlenül a szomatikus őssejtek onkogén transzformációjából származnak, hanem létrejöhetnek a szöveti sejtekben bekövetkező génmutációk és génexpressziós változások következtében, vagy akár tumoros sejtek differenciált sejtekkel és őssejtekkel való fúziójával is [14].

\section{Tumorőssejt-hipotézis és a melanoma}

\section{Melanocyta-és melanomaössejtek: jelpályák és mikrokörnyezeti hatások}

\section{Melanocyta-őssejtek differenciálódását irányító mechanizmusok}

A melanomasejtek proliferációja és differenciációja mögött olyan jelátviteli útvonalak állnak, amelyek a melanocyta-őssejtek fejlődésekor is aktiválódnak. Ezek az őssejtstádiumot szabályozó jelpályák azonban nem függetlenek a melanomát körülvevő mikrokörnyezet sejtjeitől és extracelluláris mátrix fehérjéitől, amelyek a melanocyta-őssejtek proliferációját és differenciációját is szabályozzák. Ezért a melanocyták kialakulását szabályozó mechanizmusok feltárása a melanomaőssejtek tumoriniciációban és -propagációban játszott szerepére is fényt deríthet.

A melanocyta-őssejtek neuroectoderma-eredetü sejtek, a velősánc migráló, multipotens őssejtjeiből alakulnak ki. Noha fenotipikusan igen sokféle progenitor sejt létrehozására képesek, szinte minden velőcső-eredetü őssejt membránjában megtalálható a p75 (CD271), mint kis affinitású neurotrophinreceptor. A velőcsői őssejtek migrációját epithelialis-mesenchymalis tranzíciós mechanizmusok irányítják, s e folyamatban az E-cadherin gén transzkripciós represszoraiként múködő Snail- és Slug-fehérjék kiemelkedően fontosak [15]. A multipo- tens velöcső-eredetú őssejtek osztódásaik során bipotens, gliális melanocytaprogenitorokat hoznak létre. A bispecifikus progenitorok melanoblastirányba való elköteleződésében a Wntl és Wnt3a morfogének által közvetített jelátvitel kiemelkedő szerepét igazolták [16]. A Wnt (wingless/integrated) jelpálya aktivációja, valamint következményesen a $\beta$-catenin transzkripciós faktor stabilizációja és sejtmagi transzlokációja a melanogenezisért felelős gének (microphthalmia-asszociált transzkripciós faktor - Mitf, dopachrom-tautomeráz - DCT) indukcióját vonja maga után. A Wnt-re deficiens egerekben a melanoblastok teljes hiányát mutatták ki, a $\beta$-catenin túlzott mértékú expressziója pedig a gliális előalakok elvesztését okozta a melanoblastok nagymértékü proliferációjával szemben.

Differenciációjukkal párhuzamosan a melanoblastok az epidermis basalis rétegébe, valamint a szőrtüszők külső gyökérhüvelyébe vándorolnak. Itt részesülnek azokban a szignálokban és sejt-sejt kölcsönhatásokban, amelyek a melanocytaőssejt-készlet nagyságát és differenciációját, valamint a melanocyták pigmenttermelését szabályozzák. A melanocyta-őssejtek érése a szőrtüszőben található epidermalis őssejtek és follicularis sejtek, a dermisben pedig a keratinocyták irányítása alatt áll. A belső gyökérhüvely melanocyta-őssejtjei lassan osztódó, nem pigmentált (amelanocitikus) sejtek, számuk és differenciációjuk a szőrtüszőciklus fázisaival összehangoltan változik. Az anagén fázist a melanocyta-őssejtek expanziója és a pigmentált melanocyták megjelenése kíséri, amit a catagen és telogén fázisban a tüsző regressziója és az őssejtkészlet apoptózissal való redukciója követ. $\mathrm{Az}$ egyes fázisokat jellegzetes jelátviteli mechanizmusok aktiválódása jellemzi, a jelátviteli kaszkádok génjeinek kiütése vagy csendesítése pedig az érett melanocyták és a szőrpigmentáció hiányával jár együtt. A géncsendesítéses és génkiütéses kísérletek során a melanocytaprekurzorok őssejtstádiumát fenntartó és a melanocyta-őssejtek melanoblastokká való differenciálódását stimuláló szignáltranszdukciós útvonalakat azonosítottak.

A melanocyta-őssejtek terminális differenciálódásának egyik legfontosabb mechanizmusa a Pax3 (paired box 3) és Mitf transzkripciós faktorok interakciója [17]. A Pax3 aktiválja a Mitf kifejeződését, viszont kompetitíven gátolja a Mitf kötődését a melanin-bioszintézisben kulcsszerepet játszó enzim, a DCT átírását aktiváló enhancerhez. A differenciációt a Wntl- és Wnt3a-mediált jelátviteli folyamatok aktiválják azáltal, hogy a Soxl0 ([Sex determining region Y]-box 10) transzkripciós faktor expressziójának serkentésével a Mitf és a DCT kifejeződését indukálják. A Wnt-szignalizáció és a $\beta$-catenin túlzott mértékú aktiválása, valamint a $\beta$-catenin gén csendesítése egérmodellben egyaránt a szőrpigmentáció elvesztéséhez vezetett. Előbbi esetben a szabályozatlan differenciáció folytán a melanocytaőssejt-készlet kimerülése következett be, míg a $\beta$-catenin hiányában a melanocyta-őssejtek nem voltak képesek pigmentált utódsejteket létrehozni. 
A keratinocyták által termelt őssejtfaktor (stem cell factor - SCF) a melanocyta-őssejtek érését a c-kit receptoron keresztül stimulálja. A c-kit receptorok által mediált jelátvitel nem csupán a haemopoeticus őssejtek és a melanoblastok differenciációjához szükséges, hanem a melanocyta-őssejtek migrációját is befolyásolja. Egérben, zebrahalban, valamint embernél a piebaldizmusnak nevezett autoszomális domináns betegségben a c-kit mutációja nem csak a melanocyták csökkent számával és a pigmentáció hiányával jár együtt. Azt is megfigyelték, hogy a mutációt hordozó melanocyták közelebb találhatók keletkezésük helyéhez, tehát kisebb motilitással bírtak, mint a vad típusú sejtek [18].

A neuralis és melanocyta-őssejtek differenciációs státuszát a sejt-sejt kölcsönhatások alapvetően meghatározzák. Mindkét őssejt-populációnál leírták a differenciáció lateralis gátlását, amelynek során az őssejt-populáció néhány sejtje a differenciálódás irányában elkötelezetté válik, miközben az őt körülvevő szomszédos sejtek megőrzik differenciálatlan állapotukat. A differenciált sejtek ilyen módon való kialakulását a Notch receptor és sejtfelszíni ligandjai (Jagged, Delta) szabályozzák. A NotchDelta kölcsönhatás olyan proteázokat aktivál, amelyek a Notch intracelluláris doménjét (NID) hidrolizálják. A NID-fragmens a sejtmagba transzlokálódik és az RPB-Jk (immunglobulin $\mathrm{J} \kappa$ rekombináns szignált kötő protein) transzkripciós faktorral kölcsönhatásba lépve aktiválja a differenciációért felelős géneket. A Notch-szignalizáció melanocytadifferenciációban játszott szerepét támasztja alá, hogy a NID lehasításának gamma-szekretáz-gátlókkal való megakadályozása vagy az $R P B-J \kappa$ gén deficienciája egérben depigmentált fenotípust hoz létre [19].

A differenciálódást indukáló stimulusok mellett a melanocyta-őssejtekre olyan szignálok is hatással vannak, amelyek a differenciációt gátolják, viszont a megfelelő számú őssejt fennmaradását elősegítik. A mikrokörnyezet sejtjei Wnt-szignalizációt gátló faktorokat (dab2, SRFl) és TGF- $\beta$-t (transforming growth factor $\beta$ ) szekretálnak, amely jelzőmolekuláknak kiemelkedő szerepe van az őssejtstátusz fenntartásában. Melanocyta-őssejtekben a TGF- $\beta$ receptorainak aktivációja a sejtciklus feltartóztatásához vezet és csökkenti a melanogenezist aktiváló Mitf és Pax3 fehérjék, valamint a melanin bioszintézisben részt vevő enzimek expresszióját [20].

A melanocyta-őssejtek fejlődését és fennmaradását biztosító niche-hez a megfelelő biokémiai és biomechanikai tulajdonságokkal bíró extracelluláris mátrix megléte elengedhetetlen [21]. Az extracelluláris mátrix fehérjehálózatai segítenek egymás közelségében tartani a melanocytaniche-t fenntartó és reguláló sejteket, hírvivő molekulák rezervoárjaként szolgálnak, valamint a sejtek migrációját és epithelialis-mesenchymalis transzformációját barrierként korlátozzák. A melanocytaőssejt-niche fenntartásában kiemelkedő szerep jut a tüszőkben található epithelialis (keratinocyta) őssejteknek. Az epithelőssejtek által szekretált hemidezmoszomális kollagén, a kollagén XVII hozzákapcsolja a melanocyta-őssejteket a szőrtüszők basalis membránjához. A kollagén XVII-tel való kölcsönhatás gátlása a melanocyta-őssejtek korai differenciációját és az őssejtkészlet kimerülését okozza [22].

Diszregulált mikrokörnyezet és reaktív stroma: a szöveti mikrokörnyezet és a tumorőssejtek szerepe a szolid tumorok és melanomák progressziójában

Egyre több bizonyítékunk van arra nézve, hogy a melanoma iniciációjáért, progressziójáért és drogrezisztenciájárt a pluripotens őssejtek markereivel és jelpályáival múködő sejtek felelősek. A melanoma - és más szolid tumorok - növekedéséhez és metasztázisához azonban a tumor mikrokörnyezetében található differencált sejtekre is szükség van. Ezek a tumorasszociált sejtek származhatnak a tumort körülvevő stromalis állományból vagy az immunrendszer regulátoros sejtjei is lehetnek. A tumor növekedését és terjedését támogató mikrokörnyezet a normális szöveti miliő megváltozásával jön létre, amely magában foglalja a szöveti homeosztázist szabályozó jelátviteli folyamatok, valamint a sejt-sejt kapcsolatok és az extracelluláris mátrixszal való kölcsönhatások szabályozatlanná válását [23]. A tumorasszociált fibroblastok olyan kemokinmolekulákat (CCL2, CSF1) szekretálnak, amelyek hatására a csontvelői őssejtek és a regulátoros immunsejtek a tumoros szövethez migrálnak. A tumort körülvevő szöveti niche-ben ezért krónikus gyulladásos állapot jön létre, ahol az egyre nagyobb számban megjelenő tumorinfiltráló sejtek gátolják az antitumor-immunitást, elősegítik az angiogenezist és a tumoros sejtek proliferációját.

A tumoros sejtek szekretált hírvivő molekulái, mint például a vérlemezke-eredetű növekedési faktor (PDGF) és a stromaeredetű faktor-1 (SDFl) a fibroblastokat a tumor köré toborozzák [24]. Ugyanezek a hírvivők megváltoztatják a fibroblastok génexpresszióját, amely által azok a tumor körül fibrotikusabb extracelluláris mátrixot hoznak létre. A módosult extracelluláris mátrix kihatással van a sejtadhézióhoz kapcsolt szignalizációs folyamatokra. Megfigyelték, hogy a tumorasszociált fibroblastok nagy mennyiségű kollagén I-et termelnek, amely denz hálózatot alkot és fellazítja az E-cadherinmediált sejt-sejt kölcsönhatásokat [25]. Ennek következtében a sejtekben felszabadul $\beta$-catenin, a sejtmagba transzlokálódik és proliferációt serkentő gének transzkripcióját aktiválja. A tumor és az aktivált fibroblastok olyan mátrixmetalloproteázokat is nagy mennyiségben szecernálnak, amelyek degradálják a sejtadhéziós molekulákat és az extracelluláris mátrixfehérjéket [26]. Következésképpen nő a tumorsejtek inváziója és motilitása, másrészt pedig a mátrixhoz kötött növekedési hormonok és angiogenezist promótáló faktorok (VEGF, FGF2) is felszabadulnak. A mátrixmetalloproteázok (MMP) némelyike, mint például az MMP9, szükséges a tumormikrokörnyezetben található citokinek aktiválásához. Az MMP9 metalloproteáz aktiválja a tumorok és a fibroblast sejtek által termelt TGF- $\beta-t$. Az ilyen módon akti- 
vált TGF- $\beta$ elősegíti az immunszuppresszor regulátoros T-sejtek, plazmocitoid dendritikus sejtek és M2 típusú makrofágok kialakulását, amelyek az antitumor-immunitást közvetítő citotoxikus T-sejteket és a természetes ölősejteket (natural killer vagy NK-sejtek) gátolják [27]. Spinocelluláris carcinomaőssejtekben azt is leírták, hogy a fibroblastok által szekretált TGF- $\beta$ aktiválja a carcinomaőssejtek TGFBR2 receptorait, amely mechanizmus szükséges a heterogén, drogrezisztens sejtklónok kialakulásához [28]. Fontos megjegyezni még, hogy a tumorasszociált stromasejtek nem csupán a tumor növekedéséhez és túléléséhez szükséges faktorokat és sejtkölcsönhatásokat közvetítik, hanem hozzájárulhatnak a metasztatikus tumorsejteket befogadó szöveti miliő, az úgynevezett premetasztatikus mikrokörnyezet létrehozásához. A premetasztatikus niche kialakításának hátterében meghúzódó mechanizmusok még jórészt felderítetlenek, a tumormetasztázist támogató citokinek (VEGF-A, TNF- $\alpha$ - tumornekrózis-faktor- $\alpha$ ) és sejtes elemek szerepére már kezd fény derülni.

A melanomák növekedését és progresszióját segítő niche kialakulásában a melanomaőssejtek aktívan részt vesznek. A melanomaőssejtekben is aktívak azok a jelpályák, amelyeken keresztül a keratinocyták és follicularis sejtek a melanocyták differenciációját és proliferációját szabályozzák. Sőt ugyanezen jelátviteli mechanizmusok némelyike a melanomaőssejtek epithelialis-mesenchy- malis tranzíciójában és migrációjában is fontos szerepet játszik. A TGF- $\beta$-családba tartozó jelzőmolekulák, mint maga a TGF- $\beta$, a csont morfogenikus fehérje (bone morphogenic protein - BMP) és a Nodal változatos funkciókat töltenek be a melanomaőssejtekben. A melanomaőssejtek által szekretált TGF- $\beta$ nem csupán az antitumor-immunitást szuppresszálja, hanem autokrin faktorként a melanomasejtek receptoraira is hat [29]. Ez az autokrin stimuláció a $S \operatorname{mad} 7$ transzkripciós aktivátor által közvetített módon a melanomasejtek csontvelői metasztázisát és prometasztatikus faktorok (CXCR4, osteopontin) termelését fokozza. A BMP-ről, mint az embrionális vasculogenesis egyik legfontosabb hormonjáról, bebizonyosodott, hogy a melanomasejtek angiogeneziséhez is szükséges. A melanomasejtek által szekretált BMP4 az endothelsejtek migrációját és a tumor körüli mikroérhálózat kialakulását indukálja [30]. MM-őssejtekben az embriogenezist szabályozó, a differenciált sejtekben inaktív jelpályák is reaktiválódnak. Ezek közé tartozik a Nodal, amely receptorával (Cripto-1) együtt a VGP-melanomákban fokozott mértékben koexpresszálódik. VGP-melanomából származó mintákban Elisabeth Seftor és mtsai egy speciális RNS-hibridizációs módszer (SmartFlare), valamint fluoreszcenciaaktivált sejtválogatás felhasználásával a Nodalt intenzíven és alacsony mértékben expresszáló szubpopulációkat azonosítottak [31] (1. táblázat). In vitro, a Nodalt intenzíven expresszáló

1. táblázat | Jellegzetes markerek melanomaőssejtekben

\begin{tabular}{|c|c|c|c|c|c|c|}
\hline Marker & Eredet & Egérmodell & Tumorigenicitás & Metasztázis & Gátlás/terápiás lehetőség & Referencia \\
\hline $\mathrm{CD} 20$ & Pre-B-sejtek & SCID & $\begin{array}{l}\text { Korlátlan osztódás } \\
\text { in vitro és in vivo, } \\
\text { multipotens utódsejtek }\end{array}$ & Nincs adat & $\begin{array}{l}\text { Rituximab, anti-CD20 } \\
\text { mab }\end{array}$ & {$[38]$} \\
\hline CD133 & $\begin{array}{l}\text { Haematopoeticus és } \\
\text { neuralis őssejtek }\end{array}$ & NOD/SCID & $\begin{array}{l}\text { Tumorigenezis in vivo } \\
\text { (és in vitro), bizonyos } \\
\text { sejtvonalakban } \\
\text { koexpresszió ABCB5- } \\
\text { tel vagy Nodallal }\end{array}$ & $\begin{array}{l}\text { Anti-CD133 mab } \\
\text { mellett csökkent }\end{array}$ & $\begin{array}{l}\text { Anti-CD133 } \\
\text { mab }\end{array}$ & {$[43]$} \\
\hline $\mathrm{ABCB} 5$ & Primer melanocyták & $\begin{array}{l}\text { NOD/SCID, } \\
\text { NSG }\end{array}$ & $\begin{array}{l}\text { In vivo tumorigenezis, } \\
\text { szekunder tumorok } \\
\text { létrehozása, } \\
\text { tumorheterogenitás } \\
\text { regenerálása }\end{array}$ & $\begin{array}{l}\text { Cirkuláló } \\
\text { tumorsejtek } \\
\text { NSG-egérben }\end{array}$ & $\begin{array}{l}\text { Anti ABCB5 mab } \\
\text { (ADCC, } \\
\text { tumornövekedés gátlása) }\end{array}$ & {$[42]$} \\
\hline $\mathrm{CD} 271$ & Velőcsői neuralis őssejtek & $\begin{array}{l}\operatorname{Rag} 2 \mathrm{n}^{-} / \gamma \mathrm{c}^{-} \\
\text {NSG, NOD } / \\
\text { SCID }\end{array}$ & $\begin{array}{l}\text { Heterogén, } \\
\text { multipotens tumorok } \\
\text { létrehozása, akár } 4< \\
\text { passzázs után is }\end{array}$ & $\begin{array}{l}\text { NSG és Rag } 2 \mathrm{n}^{-} / \\
\gamma \mathrm{c}^{-} \text {egérben; } \\
\text { korreláció } \\
\text { CD271-expresszióval }\end{array}$ & Nem ismert & {$[44]$} \\
\hline ALDHIA & $\begin{array}{l}\text { Haematopoeticus, } \\
\text { neuralis és } \\
\text { prosztataeredetű őssejtek }\end{array}$ & $\begin{array}{l}\text { NOD/SCID, } \\
\text { NSG }\end{array}$ & $\begin{array}{l}\text { Fokozott } \\
\text { tumorigenicitás és } \\
\text { gyógyszer-rezisztencia }\end{array}$ & Nincs adat & $\begin{array}{l}\text { In vitro siRNS; fokozott } \\
\text { gyógyszer-szenzitivitás }\end{array}$ & {$[45]$} \\
\hline Nodal & $\begin{array}{l}\text { Embrionális szövetek; } \\
\text { trophoblast, emlőmirigy }\end{array}$ & $\begin{array}{l}\text { Athymicus } \\
\text { (,nude') }\end{array}$ & $\begin{array}{l}\text { Fokozott } \\
\text { tumorigenicitás }\end{array}$ & $\begin{array}{l}\text { Fokozott áttétképzés } \\
\text { (C8161 sejtek; } \\
\text { tüdőmetasztázis } \\
\text { egérben) }\end{array}$ & $\begin{array}{l}\text { Anti-Nodal mab; } \\
\text { a metasztázis és } \\
\text { a sejttúlélés csökkent }\end{array}$ & {$[31]$} \\
\hline
\end{tabular}

ADCC = antigénfüggő celluláris citotoxicitás; mab = monoklonális antitest. 
sejtpopuláció fokozott tumorigenicitást mutatott, sőt a melanomaprogresszióval asszociált markert, a CDI33-at is kifejezte. Mivel a Nodal-szignalizáció az agresszív melanomákban szignifikánsan aktívabb, így ez a morfogén nem csupán a melanomanövekedés, hanem a melanomaprogresszió és -metasztázis biomarkerévé is válhat.

A korábbi elképzelésekkel szemben a tumorok által létrehozott érhálózatot nem kizárólagosan differenciált endothelsejtek alkotják; a vasculogenesisben endothelszerü sejtalakokká differenciálódó melanomaőssejtek is részt vesznek, amelyek denz extracelluláris mátrix létrehozása mellett képesek a tumorvasculaturába is beépülni. Az endothelsejtekből és a tumorőssejtek progenitoraiból létrejövő tubularis struktúrákon keresztül tumorsejtek, angiogenezist serkentő faktorok és tápanyagok cirkulációját figyelték meg. Ez a tumorsejteket transzformáló mechanizmus az úgynevezett vascularis mimikri, amelyet hypoxiás szöveti miliő, VEGF és differenciációt stimuláló molekulák indukálnak [32]. A vasculogenicus mimikri létrehozásában olyan agresszív cutan és uvealis melanomaszubpopulációk vesznek részt, amelyek az embrionális vasculogenesishez is nélkülözhetetlen VE-cadherin (CD144) sejtadhéziós molekulát expresszálják [33]. A VE-cadherin kritikus szerepet játszik a tumormikroérhálózat kialakulásában, mivel expressziójának csökkentése gátolta a tumor-angiogenezist és melanomasejtek vasculogenicus hálózatokba való beépülését. A vasculogenicus mimikri jelensége magyarázatként szolgálhat arra, hogy az angiogenezist gátló szerek az invazív tumorokkal szemben eddig miért nem bizonyultak kellően hatékonynak.

Nagyfokú differenciációs plaszticitásuknak köszönhetően a melanomaőssejtek nemcsak a vasculogenicus mimikriben vehetnek részt, hanem chondrocyta, adipocyta, melanocyta, glialis és neuralis sejtalakokká is transzdifferenciálódhatnak. A melanomaőssejtek proliferációját és differenciációját a melanocytaérésben és a szőrtüszőmegújulásban is szerepet játszó molekuláris mechanizmusok irányítják. A Sonic hedgehog $(\mathrm{SHH})$ mediálta jelátvitel szerepét például a tüszőérésben és a melanocytaproliferációban egyaránt igazolták, ugyanakkor kimutatták azt is, hogy az SHH a humán melanomasejtek proliferációjában és metasztázisában is szerepet játszik [34]. A melanocytaőssejtek érését szabályozó másik kulcsfontosságú mechanizmus a $\beta$-catenin stabilizációja és sejtmagi transzlokációja, amelynek szerepét a melanogenezis jelentőségében már korábban említettük. Az invazív melanomasejtek legtöbbjében a $\beta$-catenin-mutáció vagy az aberráns Wnt- és Notch-jelátvitel miatt konstitutívan aktiválódik [35]. Érdekes módon a $\beta$-catenin gén egy ritka pontmutációját Wang és mtsai az általuk vizsgált rekurrens metasztatikus tumorok mindegyikében kimutatták [36]. Ez a felfedezés amellett a hipotézis mellett szól, miszerint a melanomák metasztázisait és a primer melanomákat a tumor egy kisebb szubpopulációjának utódsejtjei hozzák létre.

\section{Össejteredetü markerek melanomában}

A szöveti és embrionális őssejtek érésük során különböző fejlődési irányba elkötelezett progrenitor sejteket hoznak létre, amelyekből a megfelelő stimulusok hatására differenciált sejtek képződnek. Az őssejtállapotra több olyan sejtfelszíni és intracelluláris fehérje expressziója jellemző, amelyek az érett sejteken nem vagy csak minimális menynyiségben, illetve eltérő kombinációban vannak jelen. A legtöbb szolid tumor belsejében és leukaemiás sejtekben is felfedeztek olyan, korlátlan osztódási potenciállal bíró sejtklónokat, amelyek jellegzetes markereket expresszáltak és heterogén tumoros sejtvonalakat hoznak létre. Ennek megfelelően a tumorőssejt-hipotézis is feltételezi olyan sejtfelszíni vagy sejten belüli markerek jelenlétét, amelyek a tumorprogresszióért felelős szubpopulációnak a többi tumorsejttől való elkülönítését elősegíthetik [37]. A potenciális tumorőssejtmarkerekkel szembeni alapfeltételezés az, hogy azok az óket hordozó sejtvonalakban szelektíven és stabilan expresszálódnak. Ennek ellenére in vitro körülmények között számos őssejteredetű fehérje expressziója dinamikus változást mutat és nem minden esetben van összhangban a sejtek osztódási potenciáljával. In vivo viszont a legtöbb xenotranszplantációs kísérletben, ahol a tumoros sejteket immunszupprimált egérbe ültették, a tumorok növekedése, differenciációs plaszticitása és metasztatizáló hajlama korrelált a vizsgált markerek jelenlétével. (A markereket és a markerpozitív melanomasejtek tulajdonságait az 1. táblázat foglalja össze.)

A CD20-at elsőként a pre-B-fázisban levő B-sejteken fedezték fel, mint a B-sejtek plazmasejtté érésében és antigén-prezentációjában szerepet játszó transzmembrán fehérjét. A melanomatumorok vizsgálatakor Fang és mtsai felfedeztek olyan nem adherens, szferoidképző tumorsejteket, amelyek a CD20-ra pozitívak voltak [38]. A CD $20^{+}$melanomasejtek sokkal multipotensebbnek bizonyultak a CD20-at nem hordozó sejteknél, olyannyira, hogy neuralis, osteocyta-, adipocyta- és chondrocytaprogenitorokhoz hasonló sejtalakokat is képesek voltak létrehozni. A CD20+ sejtek viszont nem mutattak nagyobb tumoriniciátor kapacitást a $\mathrm{CD} 20^{-}$adherens populációkhoz képest, ráadásul differenciációs képességük is idővel csökkent. Ugyanakkor a CD20 ellen kifejlesztett immunsejt- [39] és antitest-terápia [40] ígéretes eredményeket hozott a melanomasejtek progressziójának megakadályozásában. Mindez arra utal, hogy a $\mathrm{CD}^{2} 0^{+}$melanomasejteknek komoly jelentősége van a melanomák heterogenitásában és terjedésében.

A kemoterápiás szerek ellen a tumoros sejtek ABCtranszporter fehérjék upregulációjával védekeznek. Mivel az ABC-transzporterek fokozott mértékű expressziója a melanocyta-őssejtekre is jellemző tulajdonság, így elképzelhető, hogy melanomaőssejt-markerként ilyen fehérjék is szolgálhatnak. Az eddigi kutatások alapján az ABCG2 és ABCB5 fehérjék hozhatók leginkább összefüggésbe a melanomák progressziójával. Az ABCG2 
overexpressziója rezisztenciát nyújt a tumorok számára számos tirozinkináz-gátlóval (imatinib, gefitinib), antibiotikummal és HMG-CoA-reduktáz inhibitorral szemben $[41]$.

$\mathrm{Az}$ ABCB5 a doxorubicin ellen is rezisztenciát biztosít, expresszióját a primer melanomák 11\%-ában és az amelanoticus melanomasejtek 3\%-ában egyaránt kimutatták. Az ABCB5-ről cirkuláló melanomasejtekben már bizonyították, hogy képesek metasztatizálni NOD/ SCID /ILR2 $\gamma$ (NSG) egérben, sőt az ABCB5-öt expresszáló melanomasejtekben a melanoma-asszociált antigének (PDI, B7.2) és az MHCI-mediált antigén-prezentáció csökkenését is megfigyelték [42].

A CD133 (Prominin-1) a haematopoeticus és neuralis őssejteken is kifejeződő, öt transzmembrán egységes fehérje, funkciója az őssejtállapot fenntartása [43]. Mivel a melanocyta-őssejtek a migráló velőcsői neuralis őssejtekből alakulnak ki, így jogos a feltételezés, hogy a melanomaőssejtek membránjában is jelen lehet. $\mathrm{NOD}^{-} / \mathrm{SCID}$ egérben a $\mathrm{CD} 33^{+}$sejtek tumorokat hoztak létre, humán melanomás biopsziákban pedig a primer tumorok 39\%-a és a metasztázisok 46\%-a bizonyult CDl33-ra pozitívnak. Más kísérletek ugyanakkor nem minden primer melanomában és metasztázisban találtak $\mathrm{CD} 33^{+}$-szubpopulációkat, így a CD133 szerepe mint univerzális melanomaőssejt-marker egyelöre kérdéses.

A CD271 vagy p75NTR az embrionális velőcsői neuralis őssejtekben található, kis affinitású neurotrophinreceptor. A CD271 ${ }^{+}$melanomasejtek rendkívül nagy tumoriniciáló és metasztázisképző hajlammal bírnak, több egymást követő xenotranszplantáción keresztül is tumorigének [44]. Ráadásul a létrehozott tumorokon belül melanocyticus, glialis, simaizom- és neuronszerü sejtvonalak fejlődtek ki, amelyek a CD271 ${ }^{+}$tumorok multipotenciáját indikálják. A CD271 marker értékét fiziológiásan relevánsabb kísérleti körülmények között is igazolták; humán bőrből és csontszövetből vett melanomasejtek NSG-egérben szintén tumoros őssejtként viselkedtek.

Az őssejtszerű tulajdonságokat hordozó melanomasejtekben az aldehid-dehidrogenáz (ALDH) 1-es és 3-as izoenzimének magas aktivitását mérték. Ezek az enzimek az intracelluláris aldehidek metabolizálásáért felelősek, így védelmet nyújtanak az alkilálószerek széles spektrumával szemben. Luo és mtsai megmutatták, hogy az ALDHl-et expresszáló sejtek valóban a tumorőssejtekre jellemző tulajdonságokkal bírnak, és az ALDHl siRNS-sel való csendesítése e sejtek körében szenzitizáló hatású volt, a citosztatikumok által indukált sejthalál mértékét növelte [45].

\section{Tumoros össejtek és tumorszubpopulációk kialakulásának modelljei}

Jelenleg élénk tudományos vita folyik arról, hogy a tumorőssejtek vajon a tumor egy elkülönült szubpopulációját alkotják, amely a daganat terjedését és heterogén sejtklónjainak kialakulását szabályozza vagy a tumorige- nicitás és az ôssejtekre emlékeztetô plaszticitás bármely tumorsejtben kialakulhat.

A tumorőssejt-elmélet sztochasztikus modellje szerint egy tumoron belül minden sejt funkcionálisan ekvivalens, azaz bármely tumorsejt képes korlátlanul osztódó sejtté dedifferenciálódni. Az őssejtszerü állapot felvétele a környező sejtek által közvetített stimulusoktól függ, amelyek fiziológiás körülmények között a szomatikus őssejtek differenciációját szabályozzák. A hierarchikus modell alapfeltevése viszont az, hogy a tumorprogressziót tumorigén-szubpopulációk kisebb frakciója irányítja. Ezek az úgynevezett tumorössejtek, amelyek korlátlan osztódással a daganatban genetikailag és epigenetikailag heterogén tumorszubpopulációkat hoznak létre, mintegy a tumordifferenciációs hierarchia élén állva.

A hierarchikus modell érvényességét az őssejtmarkereket kifejező tumorsejtek egérszövetbe való beültetésével próbálják igazolni. A markert hordozó sejtektől azt várják, hogy a markert nem expresszáló sejtvonalakhoz viszonyítva szignifikánsan nagyobb tumorigenicitást mutatnak. A markerértékúnek tartott fehérjék legtöbbjéről eddig megállapították, hogy a tumorsejtek kis százalékában voltak kimutathatók, expressziójuk pedig korrelációt mutatott a markert hordozó sejtek agresszivitásával, gyógyszerrezisztenciájával és metasztázisképző hajlamával. Sok fehérjénél azonban megkérdőjeleződött, hogy a tumorőssejtek egyedi és stabilan kifejeződő markere lehetne. Ezzel szemben bizonyos markerek reverzibilisen expresszálódtak, azaz a markerre negatív sejtek is képesek voltak a markert expresszáló szubpopulációt létrehozni. A reverzibilis markerek sokat tanulmányozott példája közé tartozik a Jumonji/ARID hiszton-demetiláz családba tartozó H3K4 demetiláz enzim, a JARIDIB is [46]. Humán melanomás szövetmintákban és kondicionált humán embriósejtes médiumban a JARIDlB-t a melanomasejtek kis százalékában intenzív expressziót mutatott. Ezek a sejtek lassan osztódtak, ellenben nagy proliferációs kapacitással rendelkeztek. Sőt a JARIDlB-t nem expresszáló melanomasejtek is késóbb a markerre pozitívvá váltak és további fenotipikus markereikre való tekintet nélkül tumorigénnek bizonyultak. A JARIDlB-vel kapcsolatos eredmények arra hívják fel a figyelmet, hogy a tumorőssejtstátusz nem feltétlenül korlátozódik egy, a tumor belsejében található speciális sejtvonalra, azaz bármely tumoros sejt idővel az őssejtekre jellemző plaszticitást felveheti.

Szem elött kell tartani azonban, hogy egy adott markerre pozitív tumorpopuláció osztódási potenciálját és génexpressziós profilját a tumorsejt-preparáció technikája, a kondicionáló médium összetétele, valamint a xenotranszplantációhoz felhasznált egérmodell különbözőképpen befolyásolhatják [37]. Az össejtmarkereket hordozó melanomasejtek ugyan a melanomák akár kevesebb mint $1 \%$-át is alkothatják, a xenotranszplantációs esszé módosításával a tumoriniciációra képes sejtek arányát a markerexpressziós profiltól függetlenül, akár 25\%ra is megnövelhetik. Ilyen szempontból nagyon is releváns kérdés, hogy a melanomában azonosított markerek 
kijelölnek-e egy különálló, tumorigén sejtpopulációt vagy a sejtfelszíni proteom mintázattól függetlenül bármely tumorsejtklónok képesek a recipiens szövetben tumort létrehozni.

A melanomás daganatokat különösen nagy intratumor-heterogenitás jellemzi, és számos kísérleti eredmény arról tanúskodik, hogy a melanomaőssejt-populációk nem hierarchikus modell szerint vesznek részt a tumor progressziójában. Quintana és mtsai például megfigyelték, hogy a CD27l őssejtmarkerre negatív melanomasejtvonalak is képesek voltak NSG-egérben tumorok létrehozására és metasztázisok képzésére [47]. Sőt a fenotípusra való tekintet nélkül, szinte minden tumorból izolált sejt képes volt a xenotranszplantációt követően olyan tumorokat létrehozni, amelyekben már markerpozitív sejtek is jelen voltak. Kérdés marad tehát, hogy a markerek dinamikus expressziója mennyiben tudható be a kísérleti körülményeknek, illetve mennyire tükrözi a tumor természetes szöveti környezetében jelen levő fejlődési viszonyokat.

\section{Terápiás stratégiák melanoma-ôssejtmarkerekkel szemben}

Jelenlegi ismereteink szerint még kérdéses, hogy a melanomatumorokon belül elhatárolhatók-e tumorigenicitásért felelős őssejtek, azaz, hogy a tumoros őssejtek hierarchikus hipotézise a melanomára mennyire érvényes. A kérdés tisztázása kulcsfontosságú ahhoz, hogy a melanoma ellen hatékony célzott terápiákat fejleszthessünk ki. Az eddig megismert és melanoma-sejtvonalakon is azonosított markerfehérjék között azonban vannak olyanok, amelyek szerepét nem csupán a melanocyta-, hanem a melanomasejtek túlélésében, osztódásában és differenciálódásában is igazolták.

A markeralapú terápiákat két fó csoportra lehet felosztani. Az egyik megközelítés a melanomasejtek differenciációját irányító jelátviteli mechanizmusok gátlását célozza. Ilyen esetekben a melanomasejtek plaszticitásának és osztódási potenciáljának csökkenését várjuk, amely a tumor propagációját lassítja. A másik stratégia szerint a melanomasejtekben specifikusan kifejeződő sejtfelszíni antigéneket célozzuk meg. Mivel a melanomasejteken azonosított markerek a szomatikus őssejteken is jelen vannak, a specificitás hiánya és a nemkívánatos mellékhatások kockázata mindkét stratégiánál fennállhat. Ezért a módszerek hatékonyságáról és toxikus mellékhatásairól a megfelelő kísérleti modellekben való teszteléssel meg kell győződni.

A neuralis őssejtekben kifejeződő transzkripciós faktor, a Soxl0 a velőcső kialakulása mellett a melanocytaőssejtek differenciációját is szabályozza, de az őssejttulajdonságok fenntartásáért a melanomasejtekben is felelős [48]. Humán melanomasejtek xenotranszplantációjakor a Soxl0 expressziójának csökkentése az Nras p.Q61K mutációját hordozó, valamint a Soxl0 haploinszufficiens egerekben a melanomás daganatok képződését szinte teljesen meggátolta. In vitro melanomakultúrákban a
Sox 10 génjének elcsendesítése a sejtek fokozott mértékü apoptózisát, a CD271 expresszióját csökkentette, valamint gátolta a melanocytaszerű sejtalakok kialakulását. A melanomasejtek differenciációjában részt vevő jelátviteli fehérjék gátlása tehát nemcsak a tumoriniciáció ellen hat, hanem a tumorok növekedését és a heterogén tumorklónok kialakulását is megfékezheti.

A sejtfelszíni antigének közül a CD20 meglehetősen ígéretes célpontnak bizonyult a tumor-immunterápiás eljárások kidolgozásához. NSG-egerekbe xenotranszplantált melanomasejtek által létrehozott tumorokat sikeresen eradikáltak a CD20 ellen kifejlesztett citotoxikus T-sejtekkel [39]. A T-sejteket olyan kimérareceptorral transzfektálták, amelynek extracelluláris doménje egy anti-CD20 antitest antigénkötő (Fab) régióját hordozta, citoplazmatikus doménje pedig a T-sejtek aktiválódásáért felelős $\mathrm{CD} 3 \zeta$ intracelluláris doménjét tartalmazta. Humán klinikai kísérletekben IV-es stádiumban levő melanomás betegekben a rituximab (CD20 elleni antitest) a betegek kétharmadánál megakadályozta a tumorok kiújulását egy 42 hónapos megfigyelési időn belül [40]. A CD20 elleni immunterápiák ugyanakkor együtt jártak a CD20+ B-sejtek számának csökkenésével. Fontos kérdés tehát tisztázni, hogy ezek a B-sejtek tumorinfiltráló sejtekként viselkedhetnek vagy szerepük inkább az antitumor-immunitásban van.

A melanomák hisztológiai analízise során kiderült, hogy kevés melanin még az amelanocitikus melanomasejtekben is termelődik. Intracelluláris lokalizációjuk miatt melanin és a melanoszómák önmagukban monoklonális antitesttel nem targetálhatók, viszont a rapid módon növekedő melanomatumorok belsejében fellépő sejtnekrózis folytán az extracelluláris térbe melanin szivárog ki. Ezen extracelluláris melaninmolekulák ellen Thomas Jandl laboratóriuma sugárzó izotóppal $\left({ }^{188} \mathrm{Re}\right)$ jelölt monoklonális antitesteket fejlesztett ki, remélve, hogy a melanint felismerő antitestek a hozzájuk kötött $\beta$-sugárzó izotóppal célzottan károsítják a tumorsejteket [49]. Az általuk alkalmazott radioimmunterápia segítségével lényegesen csökkentették az egerekben létrehozott xenografttumorok méretét, ráadásul a tumorok belsejébe juttatott izotóp az ABCB5-re és a JARIDlB-re pozitív melanomasejtek számát szignifikáns különbség nélkül csökkentette. A tumorokhoz célzottan eljuttatható, de a melanomasejteket fenotípustól függetlenül elpusztítani képes antitestek kifejlesztése nagy segítséget nyújthat a melanomás megbetegedések hatékony kezelésében.

\section{Következtetések}

A tumorok ellen kifejlesztett terápiák és citosztatikumok legtöbbje eddig a daganatok gyorsan osztódó sejtjei ellen irányult. Az onkogének aktivitását gátló szerek ellen azonban idővel rezisztens tumorsejtklónok jelennek meg. A rezisztens tumorsejtek a citosztatikumok hatásai ellen transzporter molekulák és drogmetabolikus enzimek expressziójának fokozásával, valamint az apoptózis 
gátlásával és alternatív onkogén jelpályák aktivációjával is védekeznek. A figyelem ezért egyre inkább e heterogén és drogrezisztens tumorok kialakulásának mechanizmusai felé fordítódik. Napjainkra már számos daganattípusban azonosítottak olyan multipotens tumorsejteket, amelyek nagy tumoriniciációs potenciált hordoznak, valamint heterogén tumorsejt-fenotípusokat hoznak létre. A tumoróssejt-teória azt feltételezi, hogy a tumorok és így a melanomák terjedését és növekedését is ezek a korlátlan osztódásra és differenciációra képes sejtek irányítják. Ezt a hipotézist azok a felfedezések támasztják alá, amelyek szerint (1) a tumorok belsejében őssejtmarkereket expresszáló és (2) differenciációt szabályozó jelpályákkal szignalizáló sejteket azonosítottak. A tumorőssejtek markereinek feltárása kiemelkedő előrelépést jelenthet a daganatok növekedésének megállítására kidolgozott újabb terápiákban.

A melanomák nagyfokú heterogenitása és dinamikus sejtfelszíni fehérjeexpressziója miatt egyre inkább valószínűnek tünik, hogy a melanomasejtek bármelyike idővel pluripotens utódsejteket hozhat létre. A melanomára tehát a tumorterjedés sztochasztikus modellje lehet inkább érvényes, noha ennek eldöntéséhez még több meggyőző kísérleti bizonyíték szükséges. Amennyiben a hierarchikus modell érvényessége a melanoma progreszsziójában be is igazolódna, megválaszolandó kérdés marad, hogy a heterogén melanoma-sejtvonalak mennyire különböző módon és mértékben járulnak hozzá a daganat növekedéséhez. Ugyanakkor a feltételezett melanoma-őssejtmarkerekre (ABCB5, CD20) alkalmazott antitestek és immunterápiás stratégiák az egérmodellekben, valamint a klinikai kísérletekben igen nagy hatékonysággal kecsegtetnek. A melanoma kialakulását, heterogenitását és terjedését irányító sejtes és molekuláris mechanizmusok feltárása a betegség hatékony kezelésében és magas mortalitási arányának csökkentésében jelentős áttörést hozhat.

Anyagi támogatás: A közlemény megírását az Országos Tudományos Kutatási Alapprogramok Pályázat (OTKA NN 114460, témavezető: Prof. Dr. Kárpáti Sarolta) támogatta.

Szerzői munkamegosztás: Sz. B.: A kézirat megszövegezése. S. P., F. M., K. S., M. B., N. K.: Szakmai és kritikai javaslataikkal járultak hozzá a kézirat megalkotásához. A kézirat végleges változatát valamennyi szerző elolvasta és jóváhagyta.

Érdekeltségek: A szerzőknek nincsenek érdekeltségeik.

\section{Irodalom}

[1] Skin cancer - melanoma. American Cancer Society. http://www. cancer.org/cancer/skincancer-melanoma

[2] Balch, C. M., Soong, S. J., Gershenwald, J. E., et al.: Prognostic factors analysis of 17,600 melanoma patients: validation of the
American Joint Committee on Cancer melanoma staging system. J. Clin. Oncol., 2001, 19(16), 3622-3634.

[3] Mitchel, D. L., Fernandez, A. A.: Different types of DNA damage play different roles in the etiology of sunlight-induced melanoma. Pigment Cell Melanoma Res., 2011, 24(1), 119-124.

[4] Platz, A., Egyhazi, S., Ringborg, U., et al.: Human cutaneous melanoma; a review of NRAS and BRAF mutation frequencies in relation to histogenetic subclass and body site. Mol. Oncol., 2008, 1(4), 395-405.

[5] Udayakumar, D., Mahato, B., Gabree, M., et al.: Genetic determinants of cutaneous melanoma predisposition. Semin. Cutan. Med. Surg., 2010, 29(3), 190-195.

[6] Taylor, N. J., Busam, K. J., From, L., et al.: Inherited variation at $M C 1 R$ and histological characteristics of primary melanoma. PLoS ONE, 2015, 10(3), e0119920.

[7] Zhou, L., Yang, K., Andl, T., et al.: Perspective of targeting cancer-associated fibroblasts in melanoma. J. Cancer, 2015, 6(8), 717-726.

[8] Senft, D., Ronai, Z. A.: Immunogenic, cellular, and angiogenic drivers of tumor dormancy - a melanoma view. Pigment Cell Melanoma Res., 2016, 29(1), 27-42.

[9] Arkenau, H. T., Kefford, R., Long, G. V.: Targeting BRAF for patients with melanoma. Br. J. Cancer, 2011, 104(3), 392-398.

[10] Puntervoll, H. E., Molven, A., Akseln, L. A.: Frequencies of KIT and $G N A Q$ mutations in acral melanoma. J. Cutan. Pathol., 2014, 4l(11), 893-894.

[11] Bonnet, D., Dick, J. E.: Human acute myeloid leukemia is organized as a hierarchy that originates from a primitive, hematopoietic cell. Nat. Med., 1997, 3(7), 730-737.

[12] Vispader, J. E., Lindeman, G. J.: Cancer stem cells in solid tumours: accumulating evidence and unresolved questions. Nat. Rev. Cancer, 2008, 8(10), 755-768

[13] White, R. M., Zon, L. I.: Melanocytes in development, regeneration, and cancer. Cell Stem Cell, 2008, 3(3), 242-252.

[14] Frank, N. Y., Pendse, S. S., Lapchak, P. H., et al.: Regulation of progenitor cell fusion by ABCB5 P-glycoprotein, a novel human ATP-binding cassette transporter. J. Biol. Chem., 2003, 278(47), 47156-47165.

[15] Cano, A., Pérez-Moreno, M. A., Rodrigo, I., et al.: The transcription factor Snail controls epithelial-mesenchymal transitions by repressing E-cadherin expression. Nat. Cell Biol., 2000, 2(2), 76-83.

[16] Mort, R. L., Jackson, I. J., Patton, E. E.: The melanocyte lineage in development and disease. Development, 2015, 142(4), 620632.

[17] Lang, D., Lu, M. M., Huang, L., et al.: Pax3 functions at a nodal point in melanocyte stem cell differentiation. Nature, 2005, 433(7028), 884-887.

[18] Wehrle-Haller, B., Weston, J. A.: Soluble and cell-bound forms of steel factor activity play distinct roles in melanocyte precursor dispersal and survival on the lateral neural crest migration pathway. Development, 1995, 121(3), 731-742.

[19] Kumano, K., Masuda, S., Sata, M., et al.: Both Notchl and Notch 2 contribute to the regulation of melanocyte homeostasis. Pigment Cell Melanoma Res., 2008, 21(1), 70-78.

[20] Nishimura, E. K., Suzuki, M., Igras, V., et al.: Key roles for transforming growth factor beta in melanocyte stem cell maintenance. Cell Stem Cell, 2010, 6(2), 130-140.

[21] Ranson, M., Posen, S., Mason, R. S.: Extracellular matrix modulates the function of human melanocytes but not melanoma cells. J. Cell. Physiol., 1988, 136(2), 281-288.

[22] Gostyński, A., Pasmooij, A. M., Del Rio, M., et al.: Pigmentation and melanocyte supply to the epidermis depend on type XVII collagen. Exp. Dermatol., 2014, 23(2), 130-132.

[23] Quail, D. F., Joyce, J. A.: Microenvironmental regulation of tumor progression and metastasis. Nat. Med., 2013, 19(11), $1423-1437$. 
[24] Anderberg, C., Li, H., Fredriksson, L., et al.: Paracrine signaling by platelet-derived growth factor-CC promotes tumor growth by recruitment of cancer-associated fibroblasts. Cancer Res., 2009, 69(1), 369-378.

[25] Koenig, A., Mueller, C., Hasel, C., et al.: Collagen type I induces disruption of E-cadherin-mediated cell-cell contacts and promotes proliferation of pancreatic carcinoma cells. Cancer Res., 2006, 66(9), 4662-4671.

[26] Kessenbrock, K., Plaks, V., Werb, Z.: Matrix metalloproteinases: regulators of the tumor microenvironment. Cell, 2010, 14l(1), 52-67.

[27] Kobie, J. J., Akporiaye, E. T.: Immunosuppressive role of transforming growth factor beta in breast cancer. Clin. Applied Immunol. Rev., 2003, 3(6), 277-287.

[28] Oshimori, N., Oristian, D., Fuchs, E.: TGF- $\beta$ promotes heterogeneity and drug resistance in squamous cell carcinoma. Cell, 2015, 160(5), 963-976.

[29] Javelaud, D., Alexaki, V. I., Mauviel, A.: Transforming growth factor-beta in cutaneous melanoma. Pigment Cell Melanoma Res., 2008, 21(2), 123-132.

[30] Rothbammer, T., Bataille, F., Spruss, T., et al.: Functional implication of BMP4 expression on angiogenesis in malignant melanoma. Oncogene, 2007, 26(28), 4158-4170.

[31] Seftor, E. A., Seftor, R. E., Weldon, D. S., et al.: Melanoma tumor cell heterogeneity: a molecular approach to study subpopulations expressing the embryonic morphogen nodal. Semin. Oncol., $2014,41(2), 259-266$.

[32] Seftor, R. E., Hess, A. R., Seftor, E. A., et al.: Tumor cell vasculogenic mimicry: from controversy to therapeutic promise. Am. J. Pathol., 2012, 181(4), 1115-1125.

[33] Hendrix, M. J., Seftor, E. A., Meltzer, P. S., et al.: Expression and functional significance of VE-cadherin in aggressive human melanoma cells: Role in vasculogenic mimicry. Proc. Natl. Acad. Sci. U.S.A., 2001, 98(14), 8018-8023.

[34] Stecca, B., Mas, C., Clement, V., et al.: Melanomas require HEDGEHOG-GLI signaling regulated by interactions between GLIl and the RAS-MEK/AKT pathways. Proc. Natl. Acad. Sci. U.S.A., 2007, 104(14), 5895-5900.

[35] Sinnberg, T., Menzel, M., Ewerth, D., et al.: $\beta$-catenin signaling increases during melanoma progression and promotes tumor cell survival and chemoresistance. PLoS ONE, 2011, 6(8), e23429.

[36] Wang, E., Voiculescu, S., Le Poole, I. C., et al.: Clonal persistence and evolution during a decade of recurrent melanoma. J. Invest. Dermatol., 2006, 126(6), 1372-1377.

[37] Shakhova, O., Sommer, L.: Testing the cancer stem cell hypothesis in melanoma: the clinics will tell. Cancer Lett., 2013, 338(1), $74-81$.
[38] Fang, D., Nguyen, T. K., Leishear, K., et al.: A tumorigenic sub population with stem cell properties in melanomas. Cancer Res., 2005, 65(20), 9328-9337.

[39] Schmidt, P., Kopecky, C., Hombach, A., et al.: Eradication of melanomas by targeted elimination of a minor subset of tumor cells. Proc. Natl. Acad. Sci. U.S.A., 2011, 108(6), 2474-2479.

[40] Pinc, A., Somasundaram, R., Wagner, C., et al.: Targeting CD20 in melanoma patients at high risk of disease recurrence. Mol. Ther., 2012, 20(5), 1056-1062.

[41] Robey, R. W., Polgar, O., Deeken, J., et al.: ABCG2: determining its relevance in clinical drug resistance. Cancer Metastasis Rev., 2007, 26(1), 39-57.

[42] Schatton, T., Murphy, G. F., Frank, N. Y., et al.: Identification of cells initiating human melanomas. Nature, 2008, 451(7176), 345-349.

[43] Rappa, G., Fodstad, O., Lorico, A.: The stem cell-associated antigen CD133 (Prominin-1) is a molecular therapeutic target for metastatic melanoma. Stem Cells, 2008, 26(12), 3008-3017.

[44] Civenni, G., Walter, A., Kobert, N., et al.: Human CD271-positive melanoma stem cells associated with metastasis establish tumor heterogeneity and long-term growth. Cancer Res., 2011, 71(8), 3098-3109.

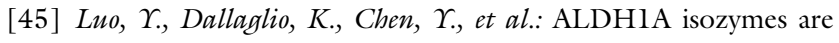
markers of human melanoma stem cells and potential therapeutic targets. Stem Cells, 2012, 30(10), 2100-2113.

[46] Roesch, A., Fukunaga-Kalabis, M., Schmidt, E. C., et al.: A temporarily distinct subpopulation of slow-cycling melanoma cells is required for continuous tumor growth. Cell, 2010, 141(4), 583594.

[47] Quintana, E., Shackleton, M., Foster, H. R., et al.: Phenotypic heterogeneity among tumorigenic melanoma cells from patients that is reversible and not hierarchically organized. Cancer Cell, $2010,18(5), 510-523$.

[48] Shakhova, O., Zingg, D., Schaefer, S. M., et al.: Sox 10 promotes the formation and maintenance of giant congenital naevi and melanoma. Nat. Cell Biol., 2012, 14(8), 882-890.

[49] Jandl, T., Revskaya, E., Jiang, Z., et al.: Melanoma stem cells in experimental melanoma are killed by radioimmunotherapy. Nucl. Med. Biol., 2013, 40(2), 177-181.

(Széky Balázs, Budapest, Hermina út 27., 1146 e-mail: szekyb@gmail.com) 